\title{
Яна ШУГАЙЛО,
}

orcid.org/0000-0003-4359-8164 кандидат педагогічних наук, доиент кафедри професійної освіти Київського національного університету технологій та дизайну (Київ, Україна) shugaylo.yv@knutd.edu.ua

\section{МОЖЛИВОСТІ ВИКОРИСТАННЯ МЕТОДИКИ SСАМРЕR ДЛЯ РОЗВИТКУ КРЕАТИВНОСТІ ЗДОБУВАЧІВ ВИЩОЇ ОСВІТИ ПІД ЧАС ВИКЛАДАННЯ ДИСЦИПЛІНИ «ОСНОВИ ІНЖЕНЕРНО-ПЕДАГОГІЧНОЇ ТВОРЧОСТІ»}

\begin{abstract}
У статті представлено досвід підготовки майбутніх фахівціів із професійної освіти в Київському національному університеті технологій і дизайну. Підготовка здобувачів вищої освіти зі спеціальності 015 «Професійна освіта» (за спеціалізаціями) має ряд особливостей, оскільки пов'язана не тільки з проєктуванням, конструюванням і виготовленням швейних виробів, а й із педагогічною діяльністю. 3 метою підготовки здобувачів освіти до творчої професійної діяльності, розвитку їхньої креативності в освітні програми «Професійна освіта (Технологія виробів легкої промисловості)», «Професійна освіта (Дизайн)» включено дисципліну «Основи інженерно-педагогічної творчості». Під час викладання дисиипліни використовується низка методик, однією з яких є SCAMPER. Метою наукового пошуку є висвітлення можливості використання методики SCAMPER для розвитку креативності здобувачів вищої освіти спеціальності 015 «Професійна освіта (за спеціалізаціями)». Здійснено аналіз наукових джерел щзодо особливостей використання методики в умовах закладів вищяої освіти. У статті розглянуто основні операції, щзо дозволяють створювати нові об'єкти або модифікувати існуючі. Наведено перелік типових питань, щзо можуть використовуватися в процесі здійснення операцій. Експериментальним шляхом перевірено можливість використання SCAMPER для створення / модифікації виробів легкої промисловості під час групової та індивідуальної роботи. Обгрунтовано ефективність методики на основі аналізу продуктивності творчого процесу слухачів курсу «Основи інженерно-педагогічної творчості». 3 'ясовано, щзо після використання SCAMPER кількість ескізів виробів індустрії моди збільшується вдвічі. Зроблено висновок, щзо методика проста у використанні й не потребує попередньої підготовки здобувачів освіти, окрім надання теоретичного матеріалу. Практичне завдання з модифікаиії об'єктів може бути виконано за 45 хвилин. Таким чином, методика сприяє розвитку дивергентного мислення, може використовуватись як у закладах професійно-технічної, так $і$ вищої освіти з метою розвитку креативності фахівців із професійної освіти.
\end{abstract}

Ключові слова: методика, SCAMPER, креативність, професійна освіта, вироби легкої промисловості.

Yana SHUHAILO, orcid.org/0000-0003-4359-8164 Candidate of Pedagogical Sciences, Associate Professor at the Department of Vocational Education Kyiv National University of Technologies and Design (Kyiv,Ukraine) shugaylo.yv@knutd.edu.ua

\section{POSSIBILITIES OF THE SCAMPER TECHNIQUE USING TO DEVELOP THE CREATIVITY OF HIGHER EDUCATION STUDENTS DURING THE TEACHING OF THE DISCIPLINE "FUNDAMENTALS OF ENGINEERING AND PEDAGOGICAL CREATIVITY”}

The article presents the experience of future professionals in vocational education training at the Kyiv National University of Technology and Design. Training of applicants for higher education of the speciality 015 "Vocational Education (by specializations)" has a number of features, as it is associated with the design, construction and manufacture of garments and pedagogical activity. To prepare students for creative professional activity, to develop their creativity to educational programs "Vocational education (Technology of light industry products)", "Vocational education (Design)" is included the discipline "Fundamentals of engineering and pedagogical creativity". During the teaching of the discipline, a number of techniques are used; among them is a SCAMPER technique. The purpose of the research is to highlight the possibility of using the SCAMPER technique to develop the creativity of higher education students majoring in 015 "Vocational Education (by specialization)". The analysis of the scientific sources concerning the features of a technique used in the conditions of higher education institutions is carried out. The article considers the basic operations that allow to create new objects or modify existing ones. The list of typical questions which can be used during the implementation of 
operations is pointed out. The possibility of using SCAMPER to create / modify light industry products during individual and group work has been experimentally tested. The effectiveness of the technique based on the analysis of the students' creative process productivity in the course "Fundamentals of engineering and pedagogical creativity" is substantiated. It has been found that after using SCAMPER, the number of sketches of fashion industry products doubles. It is concluded that the method is easy to use and does not require prior training of students. The practical task of modifying objects can be completed in 45 minutes. Thus, the method promotes the development of divergent thinking and can be used in both vocational and higher education institutions to develop the creativity of professionals in vocational education.

Key words: technique, SCAMPER, creativity, vocational education, light industry products.

Постановка проблеми. Одне із завдань закладу вищої освіти під час підготовки фахівців з професійної освіти - формування їхньої здатності до творчої професійної діяльності. Творча професійна діяльність передбачає сформованість умінь нестандартно вирішувати завдання, створювати нові продукти, що характеризуються оригінальністю, використовувати інноваційні методи та технології. Специфіка підготовки майбутніх фахівців спеціальності 015 «Професійна освіта» (за спеціалізаціями) полягає як у необхідності формування у них компетентностей щодо проєктування, конструювання та виготовлення виробів легкої промисловості, так і підготовці до викладацької діяльності. У закладах загальної середньої освіти, професійно-технічної освіти вони організовують освітній процес, обирають доцільні технології та методики викладання навчальних дисциплін, стимулюють пізнавальний інтерес та мотивацію учнів до навчання, професійне самовизначення та саморозвиток здобувачів освіти. А також забезпечують творчий розвиток учнів, який передбачає поступове формування в них здатності до творчості. На думку С. О. Сисоєвої (Сисоєва, 2006: 11), творчий розвиток учнів виступає як метою діяльності педагога, так і засобом творчого розвитку особистості самого вчителя, підвищення його професійної компетентності і рівня педагогічної майстерності.

Як зазначає О. В. Гончарова, «сформована практика навчання дисциплін швейного профілю на поточний момент орієнтує студентів не на розвиток креативності, а на оволодіння відомими технологіями й прийомами» (Гончарова, 2015: 123). Тому 3 метою розвитку креативності майбутніх фахівців з професійної освіти, під час викладання дисципліни «Основи інженернопедагогічної творчості» нами використовувалась низка методик. Серед них брейнстормінг Алекса Ф. Осборна (Alex F. Osborn), SCAMPER Алекса Ф. Осборна, модифікація Роберта Еберлі (Robert F. Eberle), «Метод фокальних об'єктів» Чарльза Вайтінга (Charles Whiting), «КАРУС» Валентина Моляко, елементи методики теорії вирішення винахідницьких задач Генріха Альтшуллера й інші. Усі вони розвивають дивергентне мислення, підвищують продуктивність, гнучкість, оригінальність, точність творчого мислення студентів. Вищезазначені методики мають відмінності у вимогах до попередньої підготовки студентів, рівні складності, часові рамки, активізують різні види творчості. Отже, актуальним $є$ питання добору такого інструментарію, що сприятиме розвитку креативності майбутніх фахівців 3 професійної освіти, оптимізуватиме процеси створення і модифікації ними виробів легкої промисловості, може бути в подальшому використаним ними при роботі з учнями різних вікових категорій з метою творчого розвитку.

Аналіз досліджень. Методика SCAMPER була розроблена Робертом Еберлі в 1971 році на основі переліку перевірочних питань А. Осборна (Alex Osborn Checklist). Назва методики $€$ акронімом для назв 7 основних операцій модифікації продукту або процесу англійською мовою (Substitute (замінити), Combine (поєднати), Adapt (адаптувати), Magnify / Modify (збільшити / модифікувати), Put to other uses (використати 3 іншою метою), Eliminate (видалити), Rearrange / Reverse (переставити / замінити на протилежність)). Методика використовується як універсальний засіб стимулювання генерування ідей, розвитку креативного мислення, його гнучкості та оригінальності.

Нами були проаналізовані наукові дослідження присвячені як власне методиці, так і особливостям іiі використання під час підготовки фахівців різних напрямів в умовах вищих навчальних закладів. Теоретичні аспекти використання методики розглянуті в роботі O. Serrat (Serrat, 2017: 311-314), ефективність іiі використання для розвитку дивергентного мислення студентів-бакалаврів університету Стамбулу досліджувала M. Ozyaprak (Ozyaprak, 2016: 31-40), розвиток креативного мислення студентів та генерування ними ідей щодо утилізації твердих відходів - D. Çelikler, G. Harman (Çelikler, Harman, 2016: 149-159), вплив на уміння розв'язувати проблеми й академічні досягнення - O. Islim та S. Karatas (Islim, Karatas, 2016: 1291-1296), SCAMPER як засіб фасилітації творчого та критичного мислення на прикладі написання літературних творів M. Idek (Idek, 2016: 30-53), вплив брейнстормінгу 
й SCAMPER на підвищення рівня творчих умінь щодо архітектурного дизайну - M. Talebi, M. Moosavi, K. Poushaneh (Talebi, Moosavi, Poushaneh, 2020: 689-706). В науковому пошуці S. Y. Choi та M.-J. Kim (Choi, Kim, 2014: 1-17), присвяченому використанню SCAMPER для дизайну модних виробів в Кореї, наведено приклади продуктів, отриманих за допомогою операцій методики та традиційних корейських зображень. На особливу увагу заслуговує дослідження ефективності впливу методики на формування навичок креативного мислення студентів мала- зійського професійного коледжу дизайну модних виробів групи дослідників А. Kamis, Widihastuti, C. Kob, G. Hustvedt, N. M. Saad, R. Jamaluddin, B. Bujeng (Kamis, Widihastuti, Kob, Hustvedt, Saad, Jamaluddin, Bujeng, 2020: 4109-4117). Спираючись на результати своїх досліджень, автори рекомендують використовувати методику для підвищення рівня креативності студентів під час розробки продуктів індустрії моди.

Мета статті - висвітлити можливості використання методики SCAMPER для розвитку креативності здобувачів вищої освіти спеціалізацій

\section{Операції методики SCAMPER}

\begin{tabular}{|c|c|c|}
\hline № & ація & Перелік типових питань при виконанні операції \\
\hline 1. & $\begin{array}{l}\text { Замінити (substitute) - замінити частину } \\
\text { продукту чи процесу чимось іншим }\end{array}$ & $\begin{array}{l}\text { Яка частина виробу може бути замінена без впливу на увесь } \\
\text { виріб? Яка частина процесу / виробу може бути замінена } \\
\text { кращою альтернативою? Чи можна замінити процес простішим } \\
\text { процесом? Що можна використати замість цього? Хто може } \\
\text { бути використаний замість цього? Які матеріали, інгредієнти, } \\
\text { процеси, потужності, звуки, підходи або сили можна замінити? } \\
\text { На яке інше місце переставити? }\end{array}$ \\
\hline 2. & $\begin{array}{l}\text { combine) - поєднати дві чи } \\
\text { стадії процесу, частини } \\
\text { тя виготовлення чогось } \\
\text { посилення взаємодії }\end{array}$ & $\begin{array}{l}\text { Чи можна об’єднати дві стадії процесу? Чи можна виконати } \\
\text { два процеси одночасно? Чи можна поєднати два компоненти } \\
\text { / технології? Що можна поєднати: змішати, зробити сплав, } \\
\text { ансамбль, суміш, асортимент? Які ідеї, цілі, одиниці чи функції } \\
\text { можна поєднати? }\end{array}$ \\
\hline 3. & $\begin{array}{l}\text { Адаптувати (adapt) - які частини } \\
\text { продукту / процесу можна адаптувати, } \\
\text { змінити природу продукту / процесу. } \\
\text { Можливі як мінімальні, так і радикальні } \\
\text { зміни продукту, в тому чисі адаптація } \\
\text { продукту до своїх потреб. }\end{array}$ & $\begin{array}{l}\text { Що необхідно змінити аби досягти кращого результату? Як } \\
\text { можна покращити існуючий процес / продукт? Як зробити } \\
\text { процес гнучким? Як відкоригувати процес / продукт? Які } \\
\text { паралелі використовувались в минулому? Що ще схоже на } \\
\text { це? Які інші ідеї це передбачає? Що можна адаптувати, щоб } \\
\text { використати у якості рішення? Що можна скопіювати? Кого } \\
\text { можна наслідувати? }\end{array}$ \\
\hline 4. & $\begin{array}{l}\text { У, } \\
\text { вати } \\
\text { и } \\
\text { ну } \\
\text { му } \\
\text { стині. }\end{array}$ & $\begin{array}{l}\text { Як модифікація продукту покращить результат? Яке інше } \\
\text { значення, колір, рух, звук, запах, форму, або вигляд це може } \\
\text { прийняти? Що можна додати? Чи можна подвоїти обсяг / розмір } \\
\text { продукту, кількість споживачів? }\end{array}$ \\
\hline 5. & $\begin{array}{l}\text { Використати інакше (put to other uses) } \\
\text { - як по-іншому можна використати } \\
\text { продукт / процес. Підлаштування } \\
\text { продукту під інших користувачів / } \\
\text { сегмент ринку. }\end{array}$ & $\begin{array}{l}\text { Які нові шляхи використання цього? Чи можна це } \\
\text { використовувати в інших місцях? На яких інших споживачів } \\
\text { можна орієнтуватись? Як цей продукт можна використати } \\
\text { по-іншому, якщо його змінити? Чи можна додати специфічний } \\
\text { етап до процесу на заміну існуючому? Чи може споживач / } \\
\text { користувач створити новий спосіб використання через власну } \\
\text { творчість? }\end{array}$ \\
\hline 6. & $\begin{array}{l}\text { Усунути (eliminate) - видалити окремі } \\
\text { частини виробу / процесу, щоб його } \\
\text { покращити. Дозволяє зосередитись на } \\
\text { непотрібних частинах продукту, процесу. }\end{array}$ & $\begin{array}{l}\text { Чи можна видалити певну функцію / корисність продукту? } \\
\text { Чи можна зменшити час виробництва / зусилля / ресурси? } \\
\text { Що можна зменшити? Що можна видалити? Чи можна } \\
\text { впорядкувати, зменшити опір? Що можна зробити меншим, } \\
\text { нижчим, коротшим чи легшим? Що можна зробити, якщо в } \\
\text { наявності лише половина ресурсів? }\end{array}$ \\
\hline 7. & $\begin{array}{l}\text { Зробити перестановку / замінити на } \\
\text { протилежність (rearrange / reverse) - } \\
\text { розташувати частини процесу / продукту } \\
\text { у зворотному порядку або упорядкувати } \\
\text { в інший спосіб }\end{array}$ & $\begin{array}{l}\text { Що можна переставити? Які інші шаблони, макети або } \\
\text { послідовності можуть бути використані? Чи можна } \\
\text { переставити / взаємозамінити компоненти, формати, моделі? } \\
\text { Чи необхідно змінити етапи, кроки, графік? Чи можна поміняти } \\
\text { місцями плюс та мінус? Чи можуть бути змінені ролі? }\end{array}$ \\
\hline
\end{tabular}


«Професійна освіта (Технології виробів легкої промисловості)» і «Професійна освіта (Дизайн)».

Виклад основного матеріалу. Процес використання методики складався з 2 етапів. На першому етапі студентам надавались основні теоретичні відомості про методику, можливі сфери iii застосування. 3 метою закріплення матеріалу, студенти отримували бланк, що містив назви та опис 7 базових операцій, а також перелік типових питань, що сприяли усвідомленню особливостей ïх виконання (табл. 1). Бланк було розроблено на основі аналізу наукових пошуків O. Serrat (Serrat, 2017: 311-314), K. Sirbiladze (Sirbiladze, 2017: 37-40).

На 2 етапі з метою формування вмінь і навичок використання методики, здобувачі вищої освіти отримували завдання обрати за власним бажанням виріб легкої промисловості та модифікувати його. Оскільки методика використовувалась студентами вперше, для створення сприятливих умов для творчості, завдання виконувалось у мікрогрупах (3-5 осіб). На виконання завдання відводилось 45 хвилин. Після чого презентувались напрацювання групи, відбувалось обговорення результатів. 3 метою закріплення умінь відбувалось повторне індивідуальне виконання завдання із обов'язковою заміною об'єкту модифікації виробу легкої промисловості. Вибір об'єкта здійснювався самими студентами. Після представ- лення робіт, академічна група обирала найбільш оригінальні ідеї, які можуть бути втілені під час професійної діяльності.

3 метою дослідження ефективності використання методики використовувався метод аналізу продуктів діяльності (за критерієм продуктивності). Було здійснено підрахунок кількості варіантів ескізів виробів, розроблених студентами груп БПТ-16, БПД-16, БПТ-17, БПД-17 (загальна кількість - 27 осіб), що навчаються в Київському національному університеті технологій і дизайну (далі - КНУТД).

До ознайомлення 3 методикою SCAMPER під час отримання завдання створити новий або модифікувати існуючий виріб легкої промисловості, обізнаність студентів щодо асортименту швейних виробів, методів конструювання, спонукала їх до використання стереотипних шляхів виконання завдання. У результаті студентами створювалось від 1 до 3 ескізів. Використання методики SCAMPER приводило до значного прогресу - всі студенти створювали $\geq 6$ ескізів. Приклади індивідуальних робіт студентів груп БПТ17 та БПД-17 щодо модифікації виробів легкої промисловості наведено на рисунках 1 та 2.

Як бачимо на рисунках, для деяких операцій студенти обирали вербальне пояснення, оскільки існували обмеження формату паперу (A-4 / A-3). За умови збільшення часу на виконання завдання

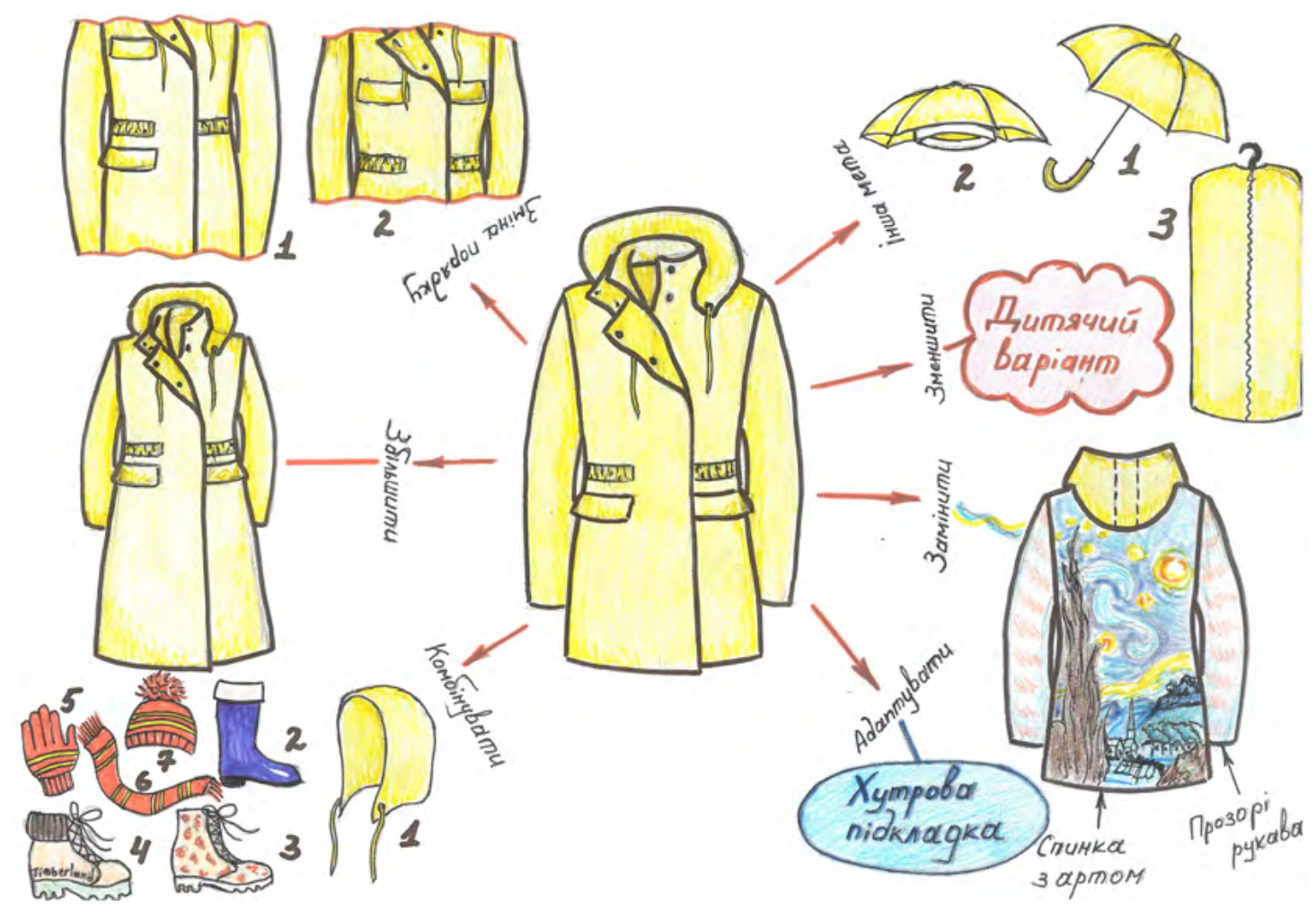

Рис. 1. Ескізи студентки X, група БПТ-17 КНУТД (7 процесів) 


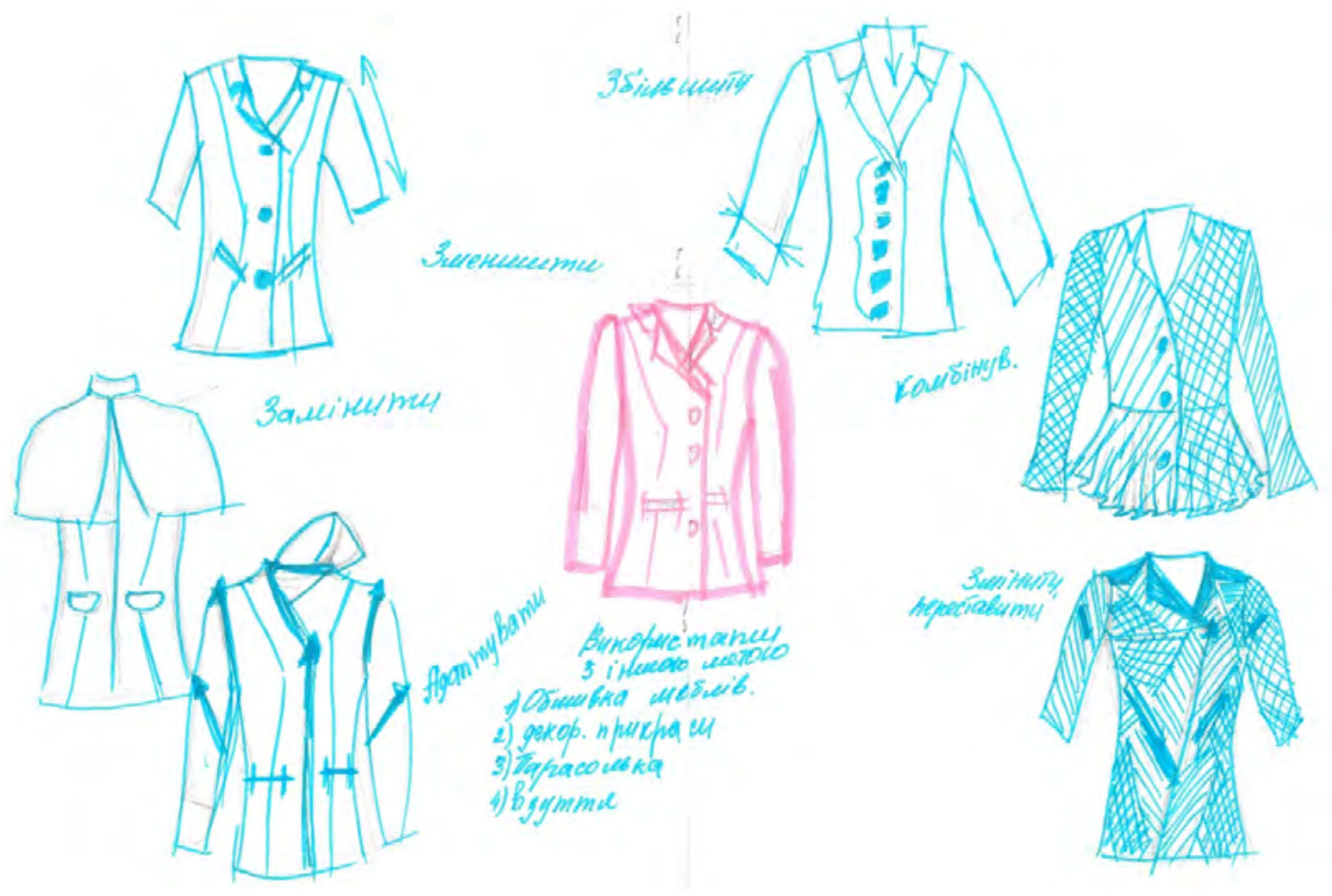

Рис. 2. Ескізи студентки У група БПД-17 (7 процесів)

вербальні варіанти вирішення завдання можуть бути замінені на ескізи. Можна зробити висновок, що продуктивність генерування ідей і створення ескізів підвищувалась вдвічі.

Під час порівняння робіт (рис. 1 та рис. 2) за однакової продуктивності виявляються відмінності в оригінальності розроблених варіантів, що може бути пояснено різним актуальним рівнем розвитку креативності студентів.

Необхідно зазначити, що виконання завдання у мікрогрупах сприяло формуванню такої компетентності, як здатність працювати в команді. В аудиторії створювалась умова психологічної безпеки і свободи, соціального підкріплення творчої поведінки, в наслідок чого підвищувався емоційний фон.

Висновки. У результаті експериментального дослідження можливості використання методики SCAMPER для розвитку креативності здобувачів вищої освіти було з'ясовано, що:

1) вона є простою у використанні, не потребує тривалої попередньої підготовки, лише ознайом- лення 3 переліком основних операцій і типовими питаннями до них;

2) під час групової роботи може бути виконана протягом 45 хвилин, що дозволяє використовувати іï у закладах як загальної середньої, так і професійно-технічної, вищої освіти;

3) може виконуватись як у мікрогрупах, так i індивідуально;

4) $є$ ефективною, дозволяє розробити $\geq 6$ ескізів нових / модифікованих виробів легкої промисловості.

Таким чином, SCAMPER може бути використана під час підготовки фахівців за освітніми програми «Професійна освіта (Технологія виробів легкої промисловості)» і «Професійна освіта (Дизайн)» із метою розвитку креативності.

Потребує подальших досліджень питання розвитку творчих здібностей здобувачів вищої освіти спеціальності 015 «Професійна освіта» (за спеціалізаціями), вибору оптимальних методик їх розвитку й експериментального дослідження їх ефективності.

\section{СПИСОК ВИКОРИСТАНИХ ДЖЕРЕЛ}

1. Сисоєва С. О. Основи педагогічної творчості : підручник. Київ : Міленіум, 2006. 344 с.

2. Гончарова О. В. Розвиток креативних здібностей у студентів - майбутніх фахівців швейного профілю. Молодь і ринок. 2015. № 6 (125). С. 121-124.

3. Serrat O. The SCAMPER Technique. Knowledge Solutions: Tools, Methods and Approaches to Drive Organizational Performance. Springer Open, Singapore, 2017. P. 311-314. URL: https://doi.org/10.1007/978-981-10-0983-9_33.

4. Ozyaprak M. The effectiveness of SCAMPER technique on creative thinking skills. Journal for the Education of Gifted Young Scientists. 2016. Nr 4 (1). P. 31-40. DOI: http://dx.doi.org/10.17478/JEGYS.2016116348.

5. Dilek Çelikler, Gonca Harman. The Effect of the SCAMPER Technique in Raising Awareness Regarding the Collection and Utilization of Solid Waste. Journal of Education and Practice. 2015. Nr 6 (10). P. 149-159. 
6. Islim O. F., Karatas S. Using The SCAMPER Technique in An ICT Course To Inhance Creative Problem Solving Skills: An Experimental Study. Turkish Online Journal of Educational Technology. 2016. Special Issue for INTE. P. 1291-1296.

7. Idek M. Measuring the Application of SCAMPER Technique in Facilitating Creative and Critical Thinking in Composing Short Stories and Poems. Malaysian Journal of Higher Order Thinking Skills in Education Edition. 2016. Nr 2. P. 30-53.

8. Talebi M., Moosavi M., Poushaneh K. Evaluating the impact of Brainstorming and Scamper technique on promoting the creativity of architectural design skills. Technology of Education Journal (TEJ). 2020. Nr 14 (3). P. 689-706. DOI: $10.22061 /$ jte.2019.5585.2243.

9. Choi S. Y., Kim M.-J. Creative Idea and an Analysis of Fashion Design on Korean Image through the SCAMPER Technique. Journal of the Korean Society of Costume. 2014. Volume 64. Issue 1. P. 1-17. URL: https://doi.org/10.7233/ jksc.2014.64.1.001.

10. Kamis A., Widihastuti, Kob C. G. C., Hustvedt G., Saad N. M., Jamaluddin R., Bujeng B. The effectiveness of SCAMPER techniques on creative thinking skills among fashion design vocational college. Eurasia J Biosci. 2020. Nr 14. P. 4109-4117.

11. Sirbiladze K. SCAMPER technique for creative thinking. Економіка, фінанси і управління в ХХІ столітті: аналіз тенденцій та перспективи розвитку : збірник тез міжнар.наук.-практ. конф., м. Київ, 21 березня 2017 р. Київ : Фінансова рада України, 2017. Т. 2. С. 37-40.

\section{REFERENCES}

1. Sysoieva S. O. Osnovy pedahohichnoi tvorchosti: pidruchnyk. [Fundamentals of pedagogical creativity: textbook]. K.: Milenium, 2006. 344 p. [in Ukrainian].

2. Honcharova O. Rozvytok kreatyvnykh zdibnostei u studentiv - maibutnikh fakhivtsiv shveinoho profiliu. [Development of creative abilities of students - future specialists in sewing]. Molod i rynok [Youth and market], 2015. Nr 6 (125), pp. 121-124. [in Ukrainian].

3. Serrat O. The SCAMPER Technique / Olivier Serrat. Knowledge Solutions: Tools, Methods and Approaches to Drive Organizational Performance. Springer Open, Singapore, 2017. pp. 311-314. https://doi.org/10.1007/978-981-10-0983-9 33.

4. Ozyaprak, M. The effectiveness of SCAMPER technique on creative thinking skills. Journal for the Education of Gifted Young Scientists, 2016, Nr 4 (1), pp. 31-40. DOI: http://dx.doi.org/10.17478/JEGYS.2016116348.

5. Dilek Çelikler, Gonca Harman. The Effect of the SCAMPER Technique in Raising Awareness Regarding the Collection and Utilization of Solid Waste. Journal of Education and Practice, 2015, $\mathrm{Nr} 6$ (10), pp. 149-159.

6. Islim O. F., Karatas S. Using The SCAMPER Technique in An ICT Course To Inhance Creative Problem Solving Skills: An Experimental Study. Turkish Online Journal of Educational Technology, 2016, Special Issue for INTE, pp. $1291-1296$.

7. Idek M. Measuring the Application of SCAMPER Technique in Facilitating Creative and Critical Thinking in Composing Short Stories and Poems. Malaysian Journal of Higher Order Thinking Skills in Education Edition, 2016, Nr 2, pp. 30-53.

8. Talebi, M., Moosavi, M., Poushaneh, K. Evaluating the impact of Brainstorming and Scamper technique on promoting the creativity of architectural design skills. Technology of Education Journal (TEJ), 2020, Nr 14 (3), pp. 689-706. doi: $10.22061 /$ jte.2019.5585.2243.

9. Choi S. Y., Kim M.-J. Creative Idea and an Analysis of Fashion Design on Korean Image through the SCAMPER Technique. Journal of the Korean Society of Costume, 2014, Volume 64, Issue 1, pp. 1-17. https://doi.org/10.7233/ jksc.2014.64.1.001

10. Kamis A., Widihastuti, Kob C. G. C., Hustvedt G., Saad N. M., Jamaluddin R., Bujeng B. The effectiveness of SCAMPER techniques on creative thinking skills among fashion design vocational college. Eurasia J Biosci, 2020, Nr 14, pp. 4109-4117.

11. Sirbiladze K. SCAMPER technique for creative thinking. Ekonomika, finansy i upravlinnia $v$ XXI stolitti: analiz tendentsii ta perspektyvy rozvytku [Economics, finance and management in the XXI century: analysis of trends and prospects]:proceedings of international scient.-pract. conference (21 of March, 2017, Kyiv). K. : Financial Council of Ukraine, 2017, V. 2, pp. 37-40. 